\title{
Regulation of the Enzymes of Lysine Biosynthesis in Bacillus sphaericus NCTC 9602 during Vegetative Growth
}

\author{
By ANNIE T. M. BARTLETT† AND P. J. WHITE* \\ Department of Microbiology, The University, Sheffield S10 2TN, UK
}

(Received 17 March 1986; revised 20 May 1986)

\begin{abstract}
Enzymes were assayed in extracts of Bacillus sphaericus harvested late in the exponential phase from batch cultures in a minimal (acetate plus salts) medium. Aspartokinase was repressed and inhibited by threonine; lysine alone had no effect, though it increased the inhibition (but not the repression) by threonine. Aspartic $\beta$-semialdehyde dehydrogenase was slightly repressed by lysine. Dihydrodipicolinate synthase was inhibited non-competitively by lysine, and dihydrodipicolinate reductase was partly repressed by lysine. Diaminopimelate dehydrogenase (with tetrahydrodipicolinate as substrate) was inhibited by meso-diaminopimelate. Lysine did not repress diaminopimelate decarboxylase, and only slightly inhibited this enzyme. An auxotrophic mutant that required threonine and methionine excreted lysine after growth had stopped with a limited concentration of threonine.
\end{abstract}

\section{INTRODUCTION}

Bacillus sphaericus uses a distinctive pathway for lysine synthesis (Fig. 1). Neither succinylated nor acetylated intermediates occur after tetrahydrodipicolinate, and diaminopimelate epimerase is absent, so that diaminopimelate dehydrogenase plays an essential role (White, 1983). Regulation of this variant pathway has not previously been studied, although much is known from other organisms about control of the earlier steps (aspartate to tetrahydrodipicolinate) which are common to all bacteria that make lysine (Umbarger, 1978).

\section{METHODS}

Organisms. Bacillus sphaericus NCTC 9602 was maintained on slopes of nutrient agar, incubated overnight at $30^{\circ} \mathrm{C}$ and stored at $2{ }^{\circ} \mathrm{C}$. Auxotrophic mutants were derived from this strain by mutation with nitrosoguanidine and penicillin-selection (White, 1983), and were similarly maintained.

Medium. The chemically defined medium A3 (White \& Lotay, 1980) was generally used for growth of liquid cultures. For some experiments, supplements of amino acids were added (as described later). The concentration of sodium acetate $3 \mathrm{H}_{2} \mathrm{O}$ was raised from $0.5 \%(\mathrm{w} / \mathrm{v})$ to $1 \%(\mathrm{w} / \mathrm{v})$ in some experiments on the excretion of lysine by mutant F28.

Conditions for growth. Cultures were grown on a mechanical shaker $\left(200\right.$ r.p.m.) at $30^{\circ} \mathrm{C}$ in liquid medium $(500 \mathrm{ml}$ per 2-1 conical flask) and harvested in the late exponential stage of growth (before sporulation).

Preparation of extracts. This was done as described by Bartlett \& White (1985). Protein was assayed by the Lowry method using crystalline bovine serum albumin as the standard.

Enzyme assays. All enzymic activities were measured at $30^{\circ} \mathrm{C}$. Every quoted activity is the mean of two or more measurements, none of which differed from the mean by more than about $10 \%$. In cases where very scattered results were at first obtained (aspartokinase, aspartic $\beta$-semialdehyde dehydrogenase) the assays were modified (see below) and determinations were repeated until consistent values were obtained. Aspartokinase (EC 2.7.2.4) was assayed by the method of Kisumi et al. (1977), modified by adding $\mathrm{NH}_{4} \mathrm{Cl}$ (final concentration $0.4 \mathrm{M}$ ) to the

† Present address: Department of Insect Pathology, Glassshouse Crops Research Institute, Worthing Road, Littlehampton, West Sussex BN17 6LP, UK. 


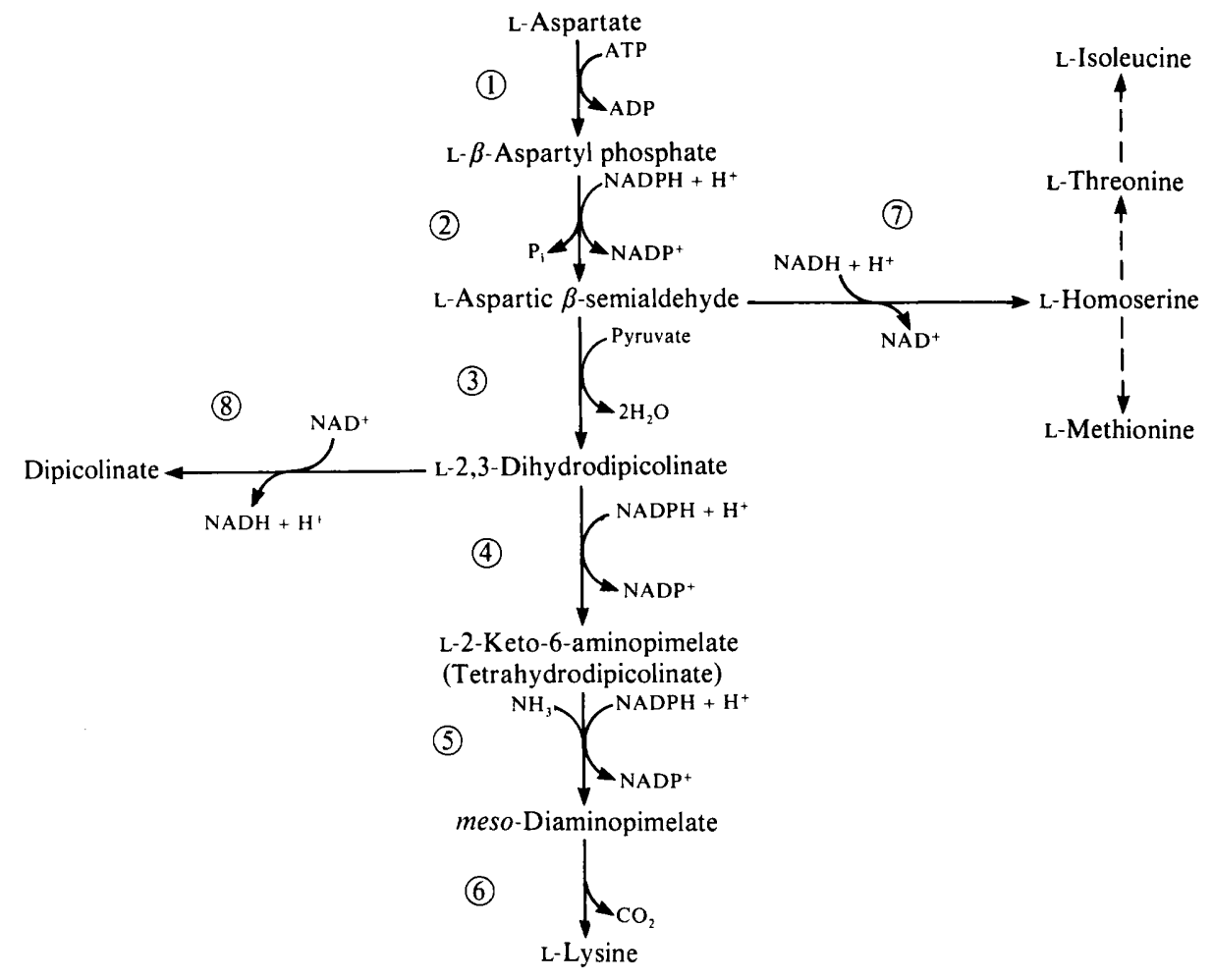

Fig. 1. The pathway of lysine biosynthesis in B. sphaericus. The enzymes are: 1, aspartokinase; 2 , aspartic $\beta$-semialdehyde dehydrogenase; 3 , dihydrodipicolinate synthase; 4 , dihydrodipicolinate reductase; 5 , diaminopimelate dehydrogenase; 6 , diaminopimelate decarboxylase; 7 , homoserine dehydrogenase; 8 , dihydrodipicolinate dehydrogenase. Threonine, isoleucine and methionine are made by separate routes from homoserine, in which several other enzymes participate.

solution incubated during the phosphorylation reaction. As was found by Paulus \& Gray (1964) with Bacillus polymyxa, a high concentration of ammonium ions was needed to measure consistent activities of aspartokinase. Aspartic $\beta$-semialdehyde dehydrogenase (EC 1.2.1.11) was assayed in the reverse of the biosynthetic direction (with aspartic $\beta$-semialdehyde as substrate), as described by Hegeman et al. (1970) but with the concentration of buffer doubled in the assay system. Dihydrodipicolinate synthase (EC 4.2.1.52; 'aspartic $\beta$-semialdehyde:pyruvate condensing enzyme') was assayed by the method of Yamakura et al. (1974). Dihydrodipicolinate reductase (EC 1.3.1.26) was assayed by the method of Kimura (1975) with substrate prepared by chemical reaction as described by White (1983). meso-Diaminopimelate D-dehydrogenase (EC 1.4.1.16) was assayed in the direction of synthesis of diaminopimelate at $\mathrm{pH} 7.5$ (Misono \& Soda, 1980) or in the reverse direction at pH 10.5 as described by Bartlett \& White (1985). Diaminopimelate decarboxylase (EC 4.1.1.20) was assayed manometrically (White, 1971). Homoserine dehydrogenase (EC 1.1.1.3) was measured in both directions of reaction by the methods of Black \& Wright (1955).

Chemicals. The preparations of aspartic $\beta$-semialdehyde, dihydrodipicolinate and L-2-amino-6-ketopimelate (tetrahydrodipicolinate) have been described before (White, 1983). meso-Diaminopimelic acid was isolated by fractional crystallization from synthetic material (Work, 1963); LL- and DD- isomers were obtained as described by Saleh \& White (1976).

Identification of lysine. Mutant F28 (met thr) was grown in medium A3 plus L-methionine and L-threonine (both $40 \mathrm{mg} \mathrm{l}^{-1}$ ). After incubation at $30^{\circ} \mathrm{C}$ for $3 \mathrm{~d}$ the organisms were centrifuged and the supernatant liquid (containing about $100 \mathrm{mg}$ lysine $1^{-1}$ ) was adjusted to $\mathrm{pH} 2$ with $\mathrm{HCl}$.This liquid (31) was passed through a column of Dowex $50\left(\mathrm{H}^{+}\right.$form; $\left.3 \times 13 \mathrm{~cm}\right)$ at a flow rate of about $3 \mathrm{ml} \mathrm{min}^{-1}$. The column was washed with water, then eluted with $2.5 \mathrm{M}-\mathrm{HCl}$ while fractions $(10 \mathrm{ml})$ were collected. Fractions that were positive in the assay (Gilvarg, 1958) for lysine were pooled and evaporated to dryness. The solid $(0.4 \mathrm{~g})$ was $70 \%(\mathrm{w} / \mathrm{w})$ lysine by assay with ninhydrin (Work, 1957). The rather complex spectrum of the coloured product (over the range 340-750 $\mathrm{nm}$ ) in this assay was identical to that given from authentic lysine. A single ninhydrin-positive spot in the same position and 
with the same distinctive colour (dull brown) as a lysine marker was found after paper chromatography of an aqueous solution $\left(1 \mathrm{mg} \mathrm{ml}^{-1}\right)$ of the solid with the solvent methanol/pyridine/11.6 M-HCl/water $(80: 10: 2 \cdot 5: 17.5$, by vol.; Rhuland et al., 1955). Finally, the solid, dissolved to a concentration of $60 \mathrm{mg} \mathrm{l}^{-1}$ in medium A3, supported growth of the lysine-requiring mutant B3 (which lacks diaminopimelate decarboxylase; White, 1983) to a final density of $0.54 \mathrm{mg}$ dry wt bacteria $\mathrm{ml}^{-1}$ (assessed from turbidity) while authentic L-lysine (40 $\mathrm{mg} \mathrm{l}^{-1}$ ) yielded $0.56 \mathrm{mg}$ dry wt bacterial $\mathrm{ml}^{-1}$. Hence, the solid was about $65 \%(\mathrm{w} / \mathrm{w})$ lysine. Mutant B3 responds to L- or to Dlysine, and so the configuration of the excreted lysine is uncertain.

\section{RESULTS}

\section{Activities of the enzymes of lysine synthesis during exponential growth in batch culture}

Bacillus sphaericus 9602 has a doubling time of about $2 \mathrm{~h}$ at $30^{\circ} \mathrm{C}$ in medium A3. If the organisms are assumed to contain $50 \%(\mathrm{w} / \mathrm{w})$ protein $(1 / 20$ of this being lysine) and $10 \%(\mathrm{w} / \mathrm{w})$ peptidoglycan (1/5 of this being lysine), then $1 \mathrm{~g}$ dry wt of bacteria will contain roughly $50 \mathrm{mg}$ of lysine residues $(0.4 \mathrm{mmol})$. Hence, the rate of lysine formation needs to be only 4-5 nmol min ${ }^{-1}$ (mg protein $)^{-1}$ to be compatible with the observed rate of growth. Measured enzymic activities in extracts were all much higher than this (Table 1), although conditions within the bacteria are unlikely to be optimal for every enzyme of the pathway to lysine. Aspartokinase and aspartic $\beta$-semialdehyde dehydrogenase must also supply homoserine, the precursor of methionine, threonine and isoleucine, and so the activities of these two enzymes need to be at least about $15 \mathrm{nmol} \min ^{-1}$ (mg protein) ${ }^{-1}$.

\section{Repression and inhibition of enzymes of lysine synthesis}

Aspartokinase. Growth in the presence of L-threonine repressed this enzyme (Table 2), whereas L-lysine on its own had no effect. Threonine at concentrations above $20 \mathrm{mg}^{-1}$ also delayed growth of $B$. sphaericus in medium A3; Lamb \& Bott (1978) found inhibition of growth of $B$. subtilis by threonine, and White (1972) reported inhibition of $B$. megaterium by this amino acid. Threonine $\left(50 \mathrm{mg} \mathrm{l}^{-1}\right)$ did not inhibit $B$. sphaericus 9602 when L-lysine and L-methionine (each $50 \mathrm{mg} \mathrm{l}^{-1}$ ) were also present in medium A3, which suggests that inhibition of growth by threonine might result from restriction of the supply of lysine and methionine by repression and inhibition of aspartokinase (see below). Diaminopimelate was not tested in the growth medium because $B$. sphaericus cannot take up this amino acid (White, 1983).

L-Threonine (in the assay mixture) inhibited aspartokinase, and lysine with threonine caused a total loss of enzymic activity, even though lysine alone did not inhibit (Table 2). The aspartokinase made at a repressed level by organisms grown with threonine was still sensitive to threonine in the assay system.

Aspartic $\beta$-semialdehyde dehydrogenase. Because aspartic $\beta$-semialdehyde is easier to prepare than $\beta$-aspartyl phosphate, this enzyme is usually assayed in the reverse of the biosynthetic direction. Consequently, any apparent regulatory effects must be viewed cautiously.

Repeated measurements of the activity of a single extract in the assay system of Hegeman et al. (1970) were erratic; much more consistent results were found when the concentration of buffer was doubled in the assay mixture. All the reported activities (Tables 1 and 3) were determined in the modified system. Lysine slightly repressed the enzyme, but no inhibition was seen with lysine, methionine or threonine.

Dihydrodipicolinate synthase. Addition of lysine $\left(50 \mathrm{mg}^{-1}\right)$ to medium A3 caused no repression. However, lysine inhibited when present in the assay mixture, whether or not the organisms had been grown with this amino acid (Fig. 2). The inhibition was non-competitive, and the $K_{\mathrm{i}}$, determined from plots by the method of Dixon (1953), was $0.6 \mathrm{M}$-L-lysine (SD 0.1 with three estimates). Individual apparent $K_{\mathrm{m}}$ values for pyruvate (measured with $3.75 \mathrm{~mm}$-aspartic $\beta$-semialdehyde always present) and for aspartic $\beta$-semialdehyde (measured with $3.75 \mathrm{~mm}$ pyruvate always present) were $9.0 \mathrm{mM}$ (SD 4.3 with three estimates) and $5.1 \mathrm{mM}$ (SD 1.4 with three estimates) respectively. These values were determined by Lineweaver-Burk plots, and are of the same order as those for this enzyme from Bacillus licheniformis (Halling \& Stahly, 1976) and from 
Table 1. Enzymic activities in extracts of B. sphaericus 9602

Enzymes were assayed (as described in Methods) in extracts of organisms grown in medium A3, and harvested during the late exponential phase.

\section{Enzyme}

Aspartokinase

Aspartic $\beta$-semialdehyde dehydrogenase

Dihydrodipicolinate synthase

Dihydrodipicolinate reductase

Diaminopimelate dehydrogenase

$\mathrm{pH} 7.5$ (ketoaminopimelate $+\mathrm{NH}_{3}+\mathrm{NADPH}$ as substrates)

pH $10 \cdot 5$ (diaminopimelate + NADP as substrates)

Diaminopimelate decarboxylase
Activity (nmol $\min ^{-1}[\mathrm{mg} \text { protein }]^{-1}$ )
$54(14)$

$43(38)$

$62^{*}(20)^{*}$

$40 \quad(29)$

$247(474)$

$452(574)$

$50 \quad(77)$

*Units (mg protein) $)^{-1}$; a unit represents about $0.50 \mathrm{nmol} \mathrm{min}{ }^{-1}$. Values in parentheses are for organisms harvested during the stationary phase, but before sporulation (from White, 1983).

\section{Table 2. Activities of aspartokinase in B. sphaericus 9602 and in mutant F28}

Organisms were grown in medium A3 with various additions, and harvested in late exponential growth. Aspartokinase was measured in extracts, with various additions to the assay system.

Enzymic activities* after growth with stated additions $\dagger$

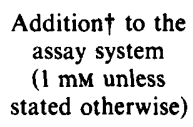

None

Thr

Lys

Thr + Lys

Thr + Met

Lys + Met

Met

Thr + Lys + Met

meso-Diaminopimelate

Thr + diaminopimelate $(2 \mathrm{mM})$

\section{$\left(50 \mathrm{mg} \mathrm{l}^{-1}\right.$ unless shown otherwise)}

\begin{tabular}{|c|c|c|c|c|c|c|}
\hline \multicolumn{5}{|c|}{ Wild-type } & \multicolumn{2}{|c|}{ Mutant F28 } \\
\hline Control & Lys & Thr & $\begin{array}{c}\text { Lys }+ \\
\text { Thr }\end{array}$ & $\begin{array}{c}\text { Lys }+ \\
\text { Thr }+ \\
\text { Met }\end{array}$ & $\begin{array}{l}\operatorname{Thr}\left(20 \mathrm{mg} \mathrm{l}^{-1}\right)+ \\
\text { Met }\left(20 \mathrm{mg} \mathrm{1}^{-1}\right)+ \\
\operatorname{lle}\left(20 \mathrm{mg} \mathrm{l}^{-1}\right)\end{array}$ & $\begin{array}{c}\text { Thr }\left(100 \mathrm{mg} \mathrm{l}^{-1}\right)+ \\
\operatorname{Met}\left(20 \mathrm{mg} \mathrm{l}^{-1}\right)+ \\
\operatorname{lle}\left(20 \mathrm{mg} \mathrm{l}^{-1}\right)\end{array}$ \\
\hline 100 & 100 & 33 & 68 & 60 & 200 & 50 \\
\hline 42 & - & 2 & - & 29 & 50 & 14 \\
\hline 110 & - & - & - & - & 200 & 50 \\
\hline 0 & - & 0 & - & 0 & 35 & 10 \\
\hline 64 & - & - & - & - & 52 & 14 \\
\hline 85 & - & - & - & - & 190 & 64 \\
\hline- & 110 & - & - & - & 150 & 50 \\
\hline 0 & - & - & - & - & 35 & 2 \\
\hline 95 & - & - & - & 53 & - & - \\
\hline 61 & - & - & - & 24 & - & - \\
\hline
\end{tabular}

* Percentages of the specific activity $\left[54 \mathrm{nmol} \mathrm{min}^{-1}(\mathrm{mg} \text { protein })^{-1}\right]$ of the enzyme from wild-type organisms grown and assayed with no additions. -, Not tested.

† All amino acids except diaminopimelate were $\mathrm{L}$ - isomers.

Table 3. Activity of aspartic $\beta$-semialdehyde dehydrogenase in extracts of B. sphaericus 9602

Organisms were grown and harvested as in Table 2. Additions to medium A3 were at $50 \mathrm{mg} \mathrm{1}^{-1}$, and additions to the assay system were at $1 \mathrm{mM}$.

Enzymic activities* after growth with státed additions

Addition to the assay system

None
Lys
Thr
Met
Lys + Thr + Met

$\overbrace{\text { Control Lys }}^{\text {Lys }+\mathrm{Thr}+\mathrm{Met}}$

$\begin{array}{lll}43 & 30 & 40 \\ 40 & - & - \\ 48 & - & - \\ 43 & - & - \\ 40 & - & -\end{array}$

* nmol $\min ^{-1}$ (mg protein) $)^{-1} ;-$, not tested. 


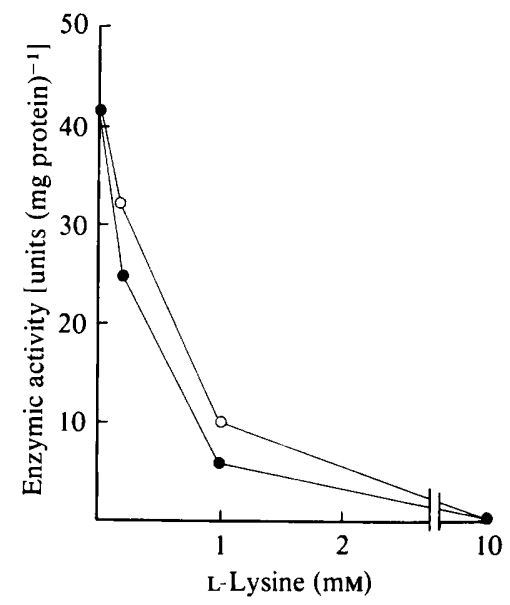

Fig. 2. Effect of lysine on dihydrodipicolinate synthase of $B$. sphaericus. O, Organisms grown in medium $\mathrm{A} 3 ; \mathrm{O}$, organisms grown in medium $\mathrm{A} 3$ plus $0.3 \mathrm{~mm}$-lysine.

Table 4. Activity of dihydrodipicolinate reductase in extracts of B. sphaericus 9602

Organisms were grown and harvested as in Table 2. Extracts were assayed at pH 6.1 except where shown otherwise. Additions to the assay system were at $1 \mathrm{~mm}$, except where stated, and additions to the medium were at $50 \mathrm{mg} \mathrm{l}^{-1}$.

Addition to the assay system

None
Lys
Thr
Met
Dipicolinate
$o$-Phenanthroline $(0.4 \mathrm{~mm})$

Enzymic activities* after growth with stated additions

Control Lys $\quad$ Lys + Thr + Met

$41,49 \dagger$
41
41
41
19
35

$30,31+$

33

$-$

$15,27+$

35

* nmol min-1 (mg protein) ${ }^{-1} ;-$, not tested.

$\dagger$ Assayed at $\mathrm{pH} 7 \cdot 2$.

Bacillus subtilis (Yamakura et al., 1974) but are more than ten times higher than those reported for Bacillus megaterium (Webster \& Lechowich, 1970) or Escherichia coli (Yugari \& Gilvarg, 1965).

Dihydrodipicolinate reductase. Lysine partly repressed the reductase (Table 4), but there was no inhibition by lysine, methionine or threonine. The effects of dipicolinic acid and $o$ phenanthroline were tested because these compounds are inhibitors in some species of Bacillus (Kimura et al., 1978). Two types of enzyme have been distinguished; one (B. subtilis type) was inhibited completely by $o$-phenanthroline and partially by dipicolinate, and had a $\mathrm{pH}$ optimum of about 6 , whereas the other (B. megaterium type) was sensitive to dipicolinate only, and had a $\mathrm{pH}$ optimum above 7 . In $B$. sphaericus, the activity of dihydrodipicolinate reductase was slightly higher at $\mathrm{pH} 7.2$ than at $\mathrm{pH} 6.1$ (the $\mathrm{pH}$ value used for tests of the inhibitors), and dipicolinate was a stronger inhibitor than $o$-phenanthroline.

Diaminopimelate dehydrogenase. meso-Diaminopimelate is easier to obtain than is ketoaminopimelate (tetrahydrodipicolinate), and so this enzyme was first assayed in the direction of oxidation of diaminopimelate (at $\mathrm{pH} 10 \cdot 5$ ). There was no repression or inhibition by lysine (Table 5). Assays in the direction of reductive amination (at $\mathrm{pH} 7.5$ ) showed that mesodiaminopimelate inhibited, while the LL- or DD- isomers had less effect. Competitive inhibition 
Table 5. Activity of diaminopimelate dehydrogenase in extracts of B. sphaericus 9602 and mutant B3

Organisms were grown and harvested as in Table 2. Additions to the assay system were at $1 \mathrm{~mm}$, except where stated, and additions to the medium were at $50 \mathrm{mg} \mathrm{l}^{-1}$.

(a) Oxidative deamination of meso-diaminopimelate, $\mathrm{pH} 10 \cdot 5$

$\begin{array}{ccc}\text { Addition to the assay system } & \begin{array}{c}\text { Enzymic activities* } \\ \text { after growth with } \\ \text { stated additions }\end{array} \\ \text { None } & \overbrace{\text { Control }}^{\text {Lys }} \\ \text { Lys } & 450 & 530 \\ \text { Met } & 520 & - \\ \text { Thr } & 630 & - \\ \text { Lys }+ \text { Thr }+ \text { Met } & 550 & - \\ & 590 & 450\end{array}$

(b) Reductive amination of 2-amino-6-ketopimelate, $\mathrm{pH} 7.5$

\begin{tabular}{|c|c|c|c|c|}
\hline \multirow{2}{*}{$\begin{array}{l}\text { Addition to the assay system } \\
\text { (all } 1.67 \mathrm{mM})\end{array}$} & \multicolumn{4}{|c|}{ Enzymic activities* after growth with stated additions } \\
\hline & Control & Lys & Thr & Lys $+\mathrm{Thr}+$ Met \\
\hline None & 250 & $190,3600 \dagger$ & 240 & 190 \\
\hline meso-Diaminopimelate & 30 &,$- 400 \dagger$ & - & - \\
\hline LL-Diaminopimelate & - &,$- 1500 \dagger$ & - & - \\
\hline DD-Diaminopimelate & - &,$- 800 \dagger$ & - & - \\
\hline
\end{tabular}

by LL- or DD-diaminopimelate has been found (Misono \& Soda, 1980) when the meso-isomer was substrate in the oxidative reaction catalysed by this enzyme. In $B$. sphaericus, diaminopimelate epimerase is absent (Bartlett \& White, 1985), so that the LL- and meso- isomers are not interconvertible. However, at pH 7.5 meso-diaminopimelate might be quickly broken down by diaminopimelate decarboxylase. Hence, the inhibition of the dehydrogenase by mesodiaminopimelate was also examined in the mutant B3, which lacks diaminopimelate decarboxylase (White, 1983). The dehydrogenase of mutant and wild-type showed similar sensitivity to meso-diaminopimelate (Table 5).

Diaminopimelate decarboxylase. In many bacteria, lysine represses this enzyme (White et al., 1964). However, with $B$. sphaericus 9602 , Grandgenett $\&$ Stahly (1971) found no repression by lysine, and very little inhibition (about $10 \%$ ) when lysine $(10 \mathrm{~mm})$ was added to the assay system. We confirmed these results, and found a slightly increased inhibition $(30 \%)$ when methionine and threonine were both present with lysine.

\section{Excretion of lysine by an auxotroph of $B$. sphaericus}

The phenotype of mutant F28, which requires methionine and threonine (but not lysine) for growth in medium A3, is indicative of the loss of homoserine dehydrogenase (see Fig. 1). Nevertheless, this enzyme was present (assayed in either direction of reaction) in crude extracts of the mutant. Possibly there are two blocks (both after homoserine) in the auxotroph, since production of multiple mutations by nitrosoguanidine is well known. One block should be in threonine synthesis and one in methionine synthesis; these presumed blocks have not been identified.

Organisms were grown in medium A3 (with amino acids, see below) and cultures were sampled at intervals. The bacteria were centrifuged, and the supernatant fluid was assayed for lysine (Work, 1957). Ornithine will react in this procedure, but the coloured product absorbs more strongly at $515 \mathrm{~nm}$ than at $440 \mathrm{~nm}$, while the opposite is true of lysine. Every test was 
therefore read at both of these wavelengths; the absorbance was always higher at $440 \mathrm{~nm}$. In addition, lysine was isolated and characterized from a culture filtrate (see Methods).

The concentration of threonine needed by the mutant was decreased on adding isoleucine, of which threonine is a precursor. When mutant F28 was given a limiting supply of L-threonine (20 $\mathrm{mg} \mathrm{l}^{-1}$ ), with L-methionine and L-isoleucine (both $20 \mathrm{mg} \mathrm{l}^{-1}$ ), about $200 \mathrm{mg}$ lysine $\mathrm{I}^{-1}$ was produced. Increasing the concentration of threonine to $60 \mathrm{mg} \mathrm{l}^{-1}$ diminished the yield of lysine to $30 \mathrm{mg} \mathrm{l}^{-1}$.

Increasing the concentration of sodium acetate $3 \mathrm{H}_{2} \mathrm{O}$ in the medium to $1 \%(\mathrm{w} / \mathrm{v})$ led to greater excretion of lysine (about $300 \mathrm{mg} \mathrm{l}^{-1}$ ) with limiting threonine. L-Aspartate (100$500 \mathrm{mg}^{-1}$ ) had little effect on lysine formation, and growth with the maximum tolerated concentration of benzylpenicillin $\left(1 \mu \mathrm{g} \mathrm{l}^{-1}\right)$ was also ineffective. The rate of formation of lysine has not been accurately measured; the amino acid accumulated over a period of about a day, after turbidity had reached its maximum but before many spores had appeared in the culture. In no case was any lysine detectable in the culture filtrate before growth had caused obvious turbidity.

Since the regulatory effect of threonine (in the wild-type) occurs on only aspartokinase, this enzyme was examined in extracts of the mutant (Table 2). Threonine caused marked repression; the enzyme that was formed at the repressed level was still inhibited by threonine. When the mutant was grown with a minimal concentration of threonine, aspartokinase had a specific activity double that of the wild-type (grown without threonine, with or without methionine plus isoleucine). The pattern of effects of inhibitors on the derepressed enzyme of the mutant was generally similar to that seen with the enzyme from the wild-type.

\section{DISCUSSION}

The means of regulation of lysine synthesis by $B$. sphaericus generally resemble those found in other bacteria. Thus, aspartokinase and dihydrodipicolinate synthase are major targets for feedback inhibition, and threonine, lysine and diaminopimelate are the principal effectors.

Without evidence from enzyme purification or genetics, it is impossible to say whether there is more than one type of aspartokinase in these organisms. The observed pattern of repression and inhibition of aspartokinase can be explained by the presence of a single enzyme, partly repressed by threonine, and subject to moderate inhibition by threonine alone, and to greater inhibition when lysine is present with threonine. No other species examined in the genus Bacillus shows precisely the same pattern: B. stearothermophilus (Kuramitsu \& Yoshimura, 1971), B. subtilis (Rosner \& Paulus, 1971) and B. cereus (Hoganson et al., 1978) all have two aspartokinases, one of which is inhibited by meso-diaminopimelate; $\boldsymbol{B}$. brevis (Hitchcock et al., 1980) has two enzymes, one repressed and inhibited by lysine, the other repressed by threonine and inhibited by threonine plus lysine; B. licheniformis (Gray \& Bernlohr, 1969), B. polymyxa (Biswas \& Paulus, 1973) and $B$. colistinus (Ito et al., 1969) all have one aspartokinase, sometimes repressed by lysine (but not by threonine) and inhibited by lysine or lysine plus threonine.

Inhibition by lysine of dihydrodipicolinate synthase (the first enzyme of the lysine-branch) has been found in many bacteria, though numerous cases of an insensitive enzyme have also been reported. If an organism needs diaminopimelate for incorporation into its peptidoglycan, then the inhibition by lysine must not be complete so that wall synthesis may go on in a medium that contains lysine. $B$. sphaericus makes a vegetative peptidoglycan without diaminopimelate (Hungerer \& Tipper, 1969), but the peptidoglycan of its spore includes diaminopimelate

Lysine does seem unable alone to shut off its own synthesis completely, because a mutant that lacks threonine will excrete lysine. However, the excretion takes place after growth has stopped, and enzymic activities have not been measured at this stage. Possibly the inhibition of dihydrodipicolinate synthase by lysine might become less, or more of the enzyme might be formed, as a preparation for sporulation, when dipicolinate and diaminopimelate are needed even when lysine may be present.

There may be an advantage to the organism in being able to decrease the activity of diaminopimelate dehydrogenase, because ammonia and NADPH will be conserved, even 
though carbon may flow through the pathway up to tetrahydrodipicolinate, and perhaps may accumulate as this compound. Whether meso-diaminopimelate (substrate at $\mathrm{pH} 10.5$ in the oxidative deamination reaction) and tetrahydrodipicolinate (substrate at $\mathrm{pH} 7.5$ in the reductive amination reaction) compete at the same binding site on the enzyme is unknown. Certainly each compound can be bound, and the presence of one may affect the reaction of the other.

A. T.M. B. was supported by a studentship from the SERC. Miss Patricia Ellison characterized the mutant F28 during her research project, and Miss Lorna Young gave excellent technical assistance in the studies of lysine excretion by this mutant.

\section{REFERENCES}

BARTLetT, A. T. M. \& White, P. J. (1985). Species of Bacillus that make a vegetative peptidoglycan containing lysine lack diaminopimelate epimerase but have diaminopimelate dehydrogenase. Journal of General Microbiology 131, 2145-2152.

Biswas, C. \& Paulus, H. (1973). Multivalent feedback inhibition of aspartokinase in Bacillus polymyxa. IV. Arrangement of the subunits. Journal of Biological Chemistry 248, 2894-2900.

BlACK, S. \& WRIGHT, N. G. (1955). Homoserine dehydrogenase. Journal of Biological Chemistry 213, 51-60.

Chatterjee, S. P. \& White, P. J. (1982). Activities and regulation of the enzymes of lysine biosynthesis in a lysine-excreting strain of Bacillus megaterium. Journal of General Microbiology 128, 1073-1081.

Dixon, M. (1953). The determination of enzyme inhibitor constants. Biochemical Journal 55, 170-171.

GILVARG, C. (1958). The enzymatic synthesis of diaminopimelic acid. Journal of Biological Chemistry 283, 1501-1504.

GrandgenetT, D. P. \& Stahly, D. P. (1971). Repression of diaminopimelate decarboxylase by L-lysine in different Bacillus species. Journal of Bacteriology 105, 1211-1212.

Gray, B. H. \& Bernlohr, R. W. (1969). The regulation of aspartokinase in Bacillus licheniformis. Biochimica et biophysica acta 178, 248-261.

Halling, S. M. \& Stahly, D. P. (1976). Dihydrodipicolinic acid synthase of Bacillus licheniformis. Quaternary structure, kinetics and stability in the presence of sodium chloride and substrates. Biochimica et biophysica acta 452, 580-596.

Hegeman, G. D., Cohen, G. N. \& Morgan, R. (1970). Aspartic semialdehyde dehydrogenase (Escherichia coli K12). Methods in Enzymology 17A, 708-713.

HitchCOCK, M. J. M., Hodgson, B. \& LiNforTH, J. L. (1980). Regulation of lysine- and lysine-plusthreonine-inhibitable aspartokinases in Bacillus brevis. Journal of Bacteriology 142, 424-432.

Hoganson, D. A., Smith, C. D. \& Stahly, D. P. (1978). Regulation of aspartokinase activity in Bacillus cereus. In Spores VII, pp. 304-307. Edited by G. Chambliss \& J. C. Vary. Washington, DC: American Society for Microbiology.

HuNGereR, K. D. \& TIPPER, D. J. (1969). Cell wall polymers of Bacillus sphaericus 9602 . 1. Structure of the vegetative cell wall peptidoglycan. Biochemistry 8, 3577-3587.

Ito, M., AIDA, K. \& Uemura, T. (1969). Studies on the bacterial formation of a peptide antibiotic, colistin III. On the biosynthetic pathway of $\alpha, \gamma$-diamino- butyric acid and relationship between colistin formation and amino acid metabolism in Bacillus colistinus KOYAMA. Agricultural and Biological Chemistry 33, 949-958.

KIMURA, K. (1975). A new flavin enzyme catalysing the reduction of dihydrodipicolinate in sporulating Bacillus subtilis. 1. Purification and properties. Journal of Biochemistry 77, 405-413.

Kimura, K., Goto, T. \& Ujita, S. (1978). Two differentiable types of dihydrodipicolinate reductase from spore-forming bacilli. In Spores VII, pp. 308311. Edited by G. Chambliss \& J. C. Vary. Washington, DC: American Society for Microbiology.

Kisumi, M., Komatsubara, S. \& Chibata, I. (1977). Enhancement of isoleucine hydroxamate-mediated growth inhibition and improvement of isoleucineproducing strains of Serratia marcescens. Applied and Environmental Microbiology 34, 647-653.

Kuramitsu, H. K. \& YoshimuRa, S. (1971). Catalytic and regulatory properties of meso-diaminopimelatesensitive aspartokinase from Bacillus stearothermophilus. Archives of Biochemistry and Biophysics 147, 683-691.

LAMB, D. H. \& BoTT, K. F. (1978). Threonine inhibition of vegetative growth and sporulation in Bacillus subtilis. In Spores VII, pp. 299-303. Edited by G. Chambliss \& J. C. Vary. Washington, DC: American Society for Microbiology.

Misono, H. \& SodA, K. (1980). Properties of meso- $\alpha, \varepsilon-$ diaminopimelate D-dehydrogenase from Bacillus sphaericus. Journal of Biological Chemistry 255, 10599-10605.

Paulus, H. \& Gray, E. (1964). Multivalent feedback inhibition of aspartokinase in Bacillus polymyxa. Journal of Biological Chemistry 239, 4008-4009.

Rhuland, L. E., Work, E., Denman, R. F. \& Hoare, D. S. (1955). The behaviour of isomers of $\alpha, \varepsilon^{-}$ diaminopimelic acid on paper chromatograms. Journal of the American Chemical Society 77, 48444846.

Rosner, A. \& Paulus, H. (1971). Regulation of aspartokinase in Bacillus subtilus. The separation and properties of two isofunctional enzymes. Journal of Biological Chemistry 246, 2965-2971.

SAlEH, F. \& WhITE, P. J. (1976). Use of auxotrophic mutants to isolate LL- and DD-isomers of 2,6diaminopimelic acid. Journal of General Microbiology 96, 253-261.

UMBARGER, H. E. (1978). Amino acid biosynthesis and its regulation. Annual Review of Biochemistry 47, 533606. 
Webster, F. H. \& Lechowich, R. V. (1970). Partial purification and characterization of dihydrodipicolinic acid synthetase from sporulating Bacillus megaterium. Journal of Bacteriology 101, 118-126.

WHITE, P. J. (1971). Diaminopimelate decarboxylase (Escherichia coli). Methods in Enzymology 17B, 140145.

WhITE, P. J. (1972). The nutrition of Bacillus megaterium and Bacillus cereus. Journal of General Microbiology 71, 505-514.

WhITE, P. J. (1983). The essential role of diaminopimelate dehydrogenase in the biosynthesis of lysine by Bacillus sphaericus. Journal of General Microbiology 129, 739-749.

White, P. J. \& LOTAY, H. K. (1980). Minimal nutritional requirements of Bacillus sphaericus NCTC 9602 and 26 other strains of this species: the majority grow and sporulate with acetate as sole major source of carbon. Journal of General Microbiology 118, 13-19.
White, P. J., Kelly, B., Suffling, A. \& Work, E. (1964). Variation of activity of bacterial diaminopimelate decarboxylase under different conditions of growth . Biochemical Journal 91, 600-610.

WORK, E. (1957). Reaction of ninhydrin in acid solution with straight chain amino acids containing two amino groups and its application to the estimation of $\alpha, \varepsilon$-diaminopimelic acid. Biochemical Journal 67, 416-423.

WoRK, E. (1963). $\alpha, \varepsilon$-Diaminopimelic acid. Methods in Enzymology 6, 624-634.

YAMAKURA, F., IKEDA, Y., KIMURA, K. \& SASAKaWa, T. (1974). Partial purification and some properties of pyruvate-aspartic semialdehyde condensing enzyme from sporulating Bacillus subtilis. Journal of Biochemistry 76, 611-621.

YugaRI, Y. \& Gilvarg, C. (1965). The condensation step in diaminopimelate synthesis. Journal of Biological Chemistry 240, 4710-4716. 